\title{
Sq field characteristics at Phu Thuy, Vietnam, during solar cycle 23: comparisons with Sq field in other longitude sectors
}

\author{
H. Pham Thi Thu ${ }^{1,2}$, C. Amory-Mazaudier ${ }^{1}$, and M. Le Huy ${ }^{2}$ \\ ${ }^{1}$ LPP/CNRS/UPMC, UMR 7648, 4 Avenue de Neptune, 94107 Saint-Maur-des-Fossés, France \\ ${ }^{2}$ Institute of Geophysics, Vietnam Academy of Science and Technology, A8, 18 Hoang Quoc Viet str. Cau Giay, Hanoi, \\ Vietnam
}

Received: 15 June 2009 - Revised: 17 November 2010 - Accepted: 15 December 2010 - Published: 4 January 2011

\begin{abstract}
Quiet days variations in the Earth's magnetic field (the Sq current system) are compared and contrasted for the Asian, African and American sectors using a new dataset from Vietnam. This is the first presentation of the variation of the Earth's magnetic field (Sq), during the solar cycle 23, at Phu Thuy, Vietnam (geographic latitudes $21.03^{\circ} \mathrm{N}$ and longitude: $\left.105.95^{\circ} \mathrm{E}\right)$. Phu Thuy observatory is located below the crest of the equatorial fountain in the Asian longitude sector of the Northern Hemisphere. The morphology of the Sq daily variation is presented as a function of solar cycle and seasons. The diurnal variation of Phu Thuy is compared to those obtained in different magnetic observatories over the world to highlight the characteristics of the Phu Thuy observations. In other longitude sectors we find different patterns.

At Phu Thuy the solar cycle variation of the amplitude of the daily variation of the $\mathrm{X}$ component is correlated to the F. $10.7 \mathrm{~cm}$ solar radiation $(\sim 0.74)$. This correlation factor is greater than the correlation factor obtained in two observatories located at the same magnetic latitudes in other longitude sectors: at Tamanrasset in the African sector $(\sim 0.42$, geographic latitude $\sim 22.79)$ and San Juan in the American sector $(\sim 0.03$, geographic latitude $\sim 18.38)$.
\end{abstract}

At Phu Thuy, the Sq field exhibits an equinoctial and a diurnal asymmetry:

- The seasonal variation of the monthly mean of X component exhibits the well known semiannual pattern with 2 equinox maxima, but the $\mathrm{X}$ component is larger in spring than in autumn. Depending of the phase of the sunspot cycle, the maximum amplitude of the X component varies in spring from $30 \mathrm{nT}$ to $75 \mathrm{nT}$ and in autumn from $20 \mathrm{nT}$ to $60 \mathrm{nT}$. The maximum amplitude of the $\mathrm{X}$ component exhibits roughly the same variation in both

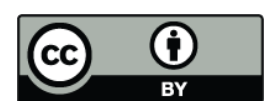

Correspondence to: H. Pham Thi Thu (hongnd76@yahoo.com) solstices, varying from about $\sim 20 \mathrm{nT}$ to $50 \mathrm{nT}$, depending on the position into the solar cycle.

- In all seasons, the mean equinoctial diurnal $\mathrm{Y}$ component has a morning maximum

Larger than the afternoon minimum i.e. the equivalent current flow over a day is more southward than northward. During winter, the asymmetry is maximum, it erases the afternoon minimum. At the Gnangara observatory, in Asian Southern Hemisphere, the diurnal Y pattern is opposite and the current flow is more northward.

It seems that in the Asian sector, the northern and southern Sq current cells both contribute strongly to the equatorial electrojet. The pattern is different in the African and American sectors where the northern Sq current cell contribution to the equatorial electrojet is smaller than the southern one. These observations can explain the unexpected maximum of amplitude of the equatorial electrojet observed in the Asian sector where the internal field is very large. During winter the $\mathrm{Y}$ component flow presents an anomaly, it is always southward during the whole day and there is no afternoon northward circulation.

Keywords. Ionosphere (Electric fields and currents) - Solar physics, astrophysics, and astronomy (Magnetic fields)

\section{Introduction}

Since several centuries the Earth's magnetic field is the object of scientific studies in various topics of geophysics (internal or external) as it integrates the influence of many physical processes. The Earth's magnetic field data were used and are still used to study ionosphere electric currents, magnetosphere electric currents, as well as atmospheric tides, ocean tides, seismicity etc.

Published by Copernicus Publications on behalf of the European Geosciences Union. 
Table 1. Coordinates of the magnetic observatories and magnetic apex coordinates at ground level using IGRF epoch 2001 (Vanzandt et al., 1972; Richmond, 1995).

\begin{tabular}{llrrrrr}
\hline \multirow{2}{*}{ Code } & \multirow{2}{*}{ Name } & \multicolumn{2}{c}{ Geographic, deg } & & \multicolumn{2}{c}{$\begin{array}{c}\text { Apex coordinates } \\
\text { (Vanzandt et al., 1972) }\end{array}$} \\
\cline { 3 - 4 } \cline { 6 - 7 } & & Lat. & Long. & & Lat. & Long. (E) \\
\cline { 3 - 4 } GNA & Gnangara & -31.78 & 115.95 & & -42.71 & -172.06 \\
HER & Hermanus & -34.42 & 19.23 & & -33.72 & 82.67 \\
MBO & M'Bour & 14.39 & 343.04 & & 20.66 & 56.82 \\
PHU & Phu Thuy & 21.03 & 105.95 & & 14.09 & 177.66 \\
SJG & San Juan & 18.38 & 293.88 & & 28.59 & 5.21 \\
TRW & Trelew & -47.270 & 294.68 & & -36.78 & 4.81 \\
BNG & Bangui & 4,440 & 18.560 & & -7.13 & 92.05 \\
TAM & Tamanrasset & 22.790 & 5.530 & & 13.18 & 79.70 \\
\hline
\end{tabular}

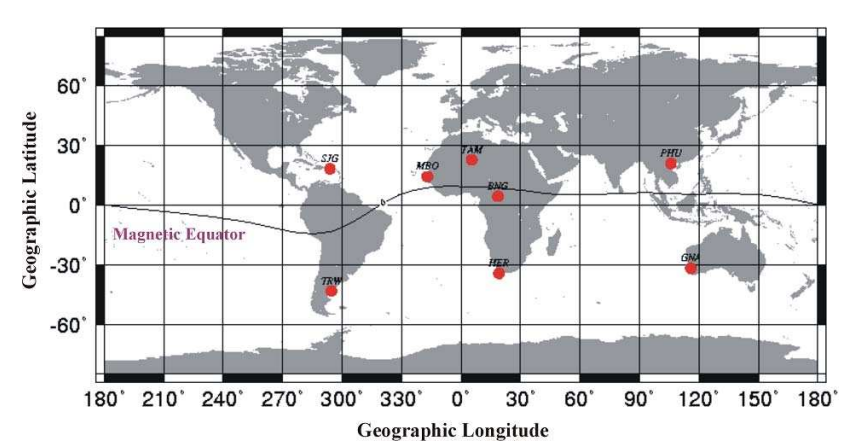

Fig. 1. Map of the world with the observatories of Phu Thuy, Gnangara, M'bour, Hermanus, San Juan, Trelew, Bangui, Tamanrasset.

In this paper we are concerned by the mean daily regular variation of Earth's magnetic field Sq (Chapman and Bartels, 1940), observed during magnetic quiet days. The existence of a conductive layer around the Earth was established by ionosonde (Breit and Tuve, 1925) and later on by rocket flights (Davis et al., 1967; Maynard, 1967; Sastri, 1968; Monro et al., 1968; Shuman, 1970; Satya Prakash et al., 1970; Sastry, 1973; Richmond, 1995a) and incoherent scatter sounders (Dougherty, 1963; Brekke et al., 1974; Kamide and Brekke, 1975; Harper, 1977; Salah and Evans, 1977; Mazaudier, 1982). In the past and still now the Sq variations were and are still intensively analyzed in all longitude sectors (Matshushita, 1965; Mayaud, 1965a, b; Campbell, 1982; Campbell and Matshushita, 1982; Doumouya, 1998; Campbell and Schiffmacher, 1985, 1986; Campbell et al., 1993; Rastogi et al., 1994; Takeda, 1999, 2002; Yamazaki et al., 2009). The Sq field strongly varies as a function of latitude and longitude. It is important to recall here that the equivalent current systems $\mathrm{Sq}$ deduced from ground magnetic variations is only a proxy of real ionosphere electric currents. $\mathrm{Sq}$ is based on the assumption of 2-D planetary cells. The true electric currents have a 3-D structure. At large scale (time and space), equivalent current systems $\mathrm{Sq}$ are a good tool to study large scale ionospheric electric currents. In this paper we analyze the Sq of Phu Thuy (Vietnam) during the solar cycle 23 in order to characterize it. This is the first step in our study of ionospheric electric currents in Vietnam. Our study is developed in the frame of the international programmes IHY and CAWSES (Amory-Mazaudier et al., 2006). The first section of the paper presents the data set and the data analysis and the second section the solar cycle variations of the Sq at Phu Thuy. The third section is devoted to the seasonal variations in the various selected magnetic observatories and section four to the mean daily variation of the Earth's magnetic field. Finally the comparison with variations of other stations reveals a series of facts that will need data from more stations and considerable theoretical works.

\section{Data set and data analysis}

The data used are the daily regular variation of the Earth's magnetic field recorded at Phu Thuy-Viet Nam during the solar cycle 23 (lasting from 1996 to 2006). We also use the Earth's magnetic field data recorded in different observatories of the INTERMAGNET network at mid-latitude, in the three longitude sectors (Asian, African, and American) and the two hemispheres. Figure 1 shows the position of the magnetic observatories selected: San Juan, Trelew in the American sector, M'bour, Tamanrasset Bangui, Hermanus, in the African sector and Phu Thuy and Gnangara in the Asian sector. Table 1 lists the geographic coordinates and Magnetic Apex coordinates at ground level using IGRF epoch 2001, for all the observatories (Vanzandt et al., 1972; Richmond, 1995b).

The INTERMAGNET data base provides the horizontal and vertical components of the Earth's magnetic field ( $H$, $Z$ ), the declination $(D)$, and total field $F$, as well as the northward and eastward components $(X, Y)$. 


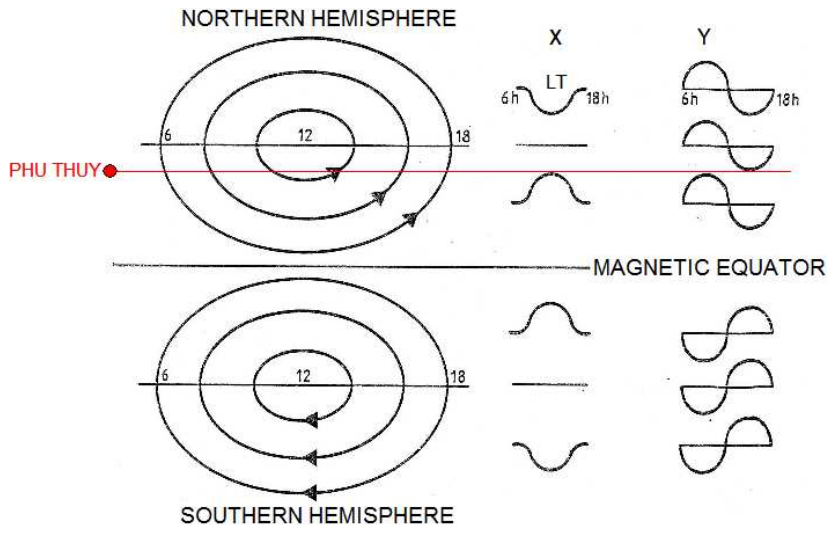

Fig. 2. Sq equivalent current system composed of two current cells.

In this paper, we analyze the diurnal, seasonal and solar variations of $\mathrm{X}$ and $\mathrm{Y}$ components during magnetic quiet days, of the solar cycle 23. The magnetic quiet days are selected with a daily magnetic index am $<20 \mathrm{nT}$.

The $\mathrm{X}$ and $\mathrm{Y}$ monthly mean diurnal variations are computed as the arithmetical mean of the hourly local time mean values after the subtraction of night-time level (23:0002:00 LT) (Tarpley, 1973).

$X=\frac{1}{n} \sum_{i=1}^{n} x_{i}$

Where $i$ equal $1, \ldots 24$.

The seasonal variations are obtained by making the monthly arithmetical mean of those months comprising a given season. Our seasons are the following: winter (November, December, January, and February), summer (May, June, July, August), autumn (September, October), spring (March, April). We consider spring and autumn separately, this is a novelty.

The amplitude of the monthly mean diurnal variation of the $\mathrm{X}$ component is the maximum value of the mean diurnal variation of $\mathrm{X}$ component and the amplitude of the monthly mean diurnal variation of the $\mathrm{Y}$ component is given by the distance between the maximum and the minimum of the mean diurnal variations of the Y component.

The error bars are given by

$\sigma=\sqrt{V}$

where $V$ is the variance, provide an estimation of the uncertainty in the components of the magnetic field.

We also computed the seasonal tendency:

$\Delta X_{i}=X_{i}-<X>$

where $X_{i}$ is to the monthly mean values and $\langle X\rangle$ is an approximation of the mean annual value by using linear regression.

The study is performed for the different phases of solar cycles. We distinguish four parts: the minimum phase, years with $R_{z}<20$, the increasing phase, years with $20 \leq R_{z} \leq$ 100 , the maximum phase, years with $R_{z}>100$ and the decreasing phase, years with $100 \geq R_{z} \geq 20$.

We analyze also Fourier transform of the diurnal variation of the Y component to determine the reversal time of the diurnal variation of the $\mathrm{Y}$ component from East to West during the daytime.

It should be pointed out that our analysis of the Sq field actually includes both ionospheric and non-ionospheric sources. The latter can be divided into internal and external contributions. For example, Olson (1989) found that magnetospheric currents contribute about 12 nanoteslas to the dayto-night difference in the mid-latitude Sq pattern for steady, quiet magnetospheric conditions. Thus, the subtraction of the night-time level actually does not withdraw the influence of all the magnetospheric currents on $\mathrm{Sq}$ variation. The internal part of the $\mathrm{Sq}$ is produced by the induced electric currents generated by the external sources. At middle and high latitudes the induced field can account for $33 \%$ or more of the external field (Kamide and Brekke, 1975; Kuvshinov et al., 2007) and at low latitudes few percents (Fambitakoye, 1973).

Figure 2 illustrates the well known Sq current system. This schematic figure do not represent observations, it is simple pattern useful to approach the complex reality. The Sq current system assumes "equivalent currents" flowing in an infinite plane sheet over a plane earth; it is a 2-D system. The $\mathrm{Sq}$ is composed of 2 cells, one for each hemisphere (left side, Fig. 2). The current flows clockwise in the Southern Hemisphere and anticlockwise in the northern one. The daily variation of the $X(H)$ and the $Y(D)$ components are drawn on the right side of Fig. 2. In the Northern Hemisphere the $X$ component is negative (southward) above the focus of the $\mathrm{Sq}$, nil at the focus, and positive (northward) below the focus. The Y component is positive (eastward) in the morning and negative (westward) in the afternoon for all the northern latitudes. The reverse pattern is observed in the Southern Hemisphere. Along the equator the equatorial electrojet is assumed as an equivalent ribbon of current (1-D) circulating toward the East (not drawn on Fig. 2).

Following Ampere's law a northward magnetic field variation corresponds to an eastward ionospheric electric current, and an eastward magnetic field variation to a southward ionospheric electric current.

Figure 3 shows a typical daily regular variation $S_{R}$ of the Earth's magnetic field defined by Mayaud in 1965 observed at Phu Thuy on an individual quiet magnetic day. The northward X component is on the left panel and the eastward $\mathrm{Y}$ component on the right one. These observations can be roughly explained by the motion of the station below a plane infinite sheet of current, at latitudes below the focus of the Sq current system in the Northern Hemisphere (see Fig. 2).

At Phu Thuy, during magnetic quiet days, the ionospheric electric current flows in East South direction in the morning and in East North direction in the afternoon. We must notice that the amplitude of the Y component in the morning 

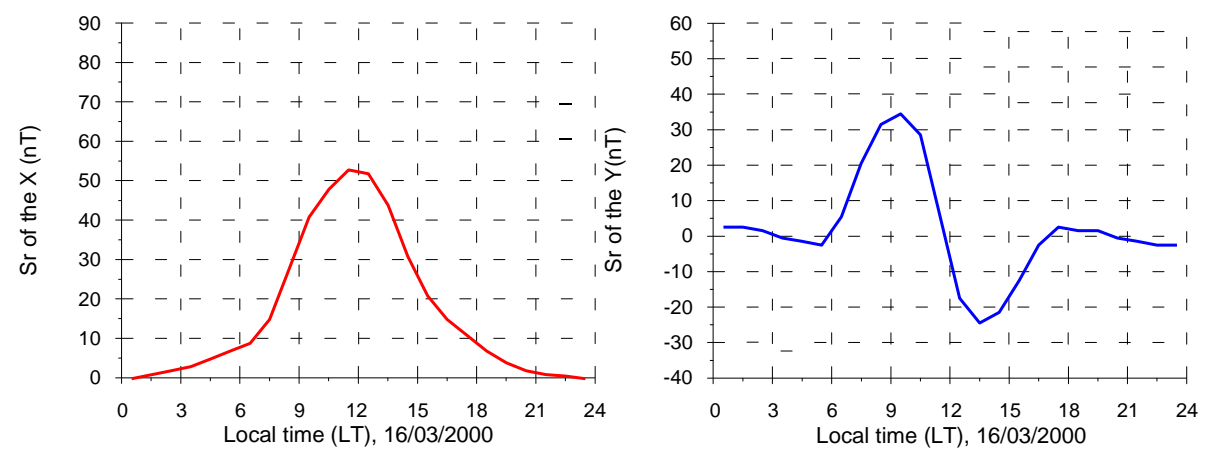

Fig. 3. $S_{R}$ observed at Phu Thuy on 16 March 2000, a very quiet day $\Sigma \mathrm{Am}=3$.

Table 2. Correlation of the $\mathrm{X}$ and $\mathrm{Y}$ components of the Earth's magnetic field with F10.7, for all the observatories of Table 1.

\begin{tabular}{lrr}
\hline Stations & $\begin{array}{r}\text { Correlation coefficient } \\
\text { X with F10.7 }\end{array}$ & $\begin{array}{r}\text { Correlation coefficient } \\
\text { Y with F10.7 }\end{array}$ \\
\hline PhuThuy & 0.74 & 0.40 \\
Gnangara & -0.43 & 0.44 \\
Tamanrasset & 0.42 & 0.17 \\
Hermanus & -0.38 & 0.39 \\
M'bour & 0.34 & 0.10 \\
Bangui & 0.79 & 0.42 \\
Trelew & -0.13 & 0.42 \\
Sanjuan & 0.03 & 0.52 \\
\hline
\end{tabular}

$(\sim 35 \mathrm{nT})$ is greater than the amplitude of the $\mathrm{Y}$ component during afternoon $(\sim 25 \mathrm{nT})$.

\section{Solar cycle variations}

Figure 4 illustrates the solar cycle variation of the monthly mean value of F10.7 index (panel a) and the amplitude of the monthly arithmetical mean diurnal variation of magnetic field components X (panel b) and Y (panel c) recorded at Phu Thuy. On all the panels the smooth line is the average variation. The $\mathrm{X}$-component (panel b) varies with the sunspot cycle; the Y component (panel c) is poorly correlated with sunspot number. The amplitude of the Y component (D component) increases with the magnetic latitude of the stations involved in our study. This result was found at first by Mascart (1900). The amplitude of the X component (H component) is related to the station location relatively to the focus Sq system. Near the focus of the Sq system, the amplitude is smaller. Recently, Yamazaki et al. (2009) demonstrated that annual variation is predominant in $\mathrm{Y}$ (or D) component and semiannual variation is predominant in $\mathrm{X}$ (or $\mathrm{H}$ ) component near the geomagnetic equator, and the amplitude of the an- nual variation is greater than the semiannual variation, which is consistent with the result as shown in Fig. 4.

The fact that the seasonal variation of the $\mathrm{X}$ component is smaller than the seasonal variation of the Y component implies that the location of the station of Phu Thuy relatively to the focus of the Sq system is rather the same for the different seasons during all the year.

Table 2, column 2 gives, for all the selected observatories, the correlation coefficients between the $\mathrm{X}$ component and the F10.7 index, and column 3 the correlation coefficient between the Y component and the F10.7 index. The correlation coefficients between $\mathrm{X}$ and F10.7 are rather good at Phu Thuy (0.74) and Bangui (0.79). The correlation coefficients between Y and F10.7 are not significant for Phu Thuy and Bangui.

For all other observatories the two correlation factors are not significant. Recently, at Livingston Island, Torta et al. (2010) found a clear dependence of the Sq amplitude on solar activity and that the maximum amplitude of the Sq occurs about 2 years later than the sunspot maximum.

\section{Seasonal variations}

Figure 5 illustrates the monthly mean diurnal $\Delta X$ (left side) and $\Delta Y$ components (right side) at Phu Thuy for the different phases of the sunspot cycle, see Eq. (3). From the top to the bottom are shown the minimum, increasing, maximum and decreasing phases of the sunspot cycle.

In Fig. 5, left side, the $\Delta X$ component exhibits a semiannual variation; highest values are observed near equinoxes and minima near solstices during all the phases of the sunspot cycle. The first maximum of the $\Delta X$-component arises always in March or in April, whereas the second maximum appears generally in October and sometimes in November. The asymmetry between equinoxes and solstices is observed in annual variation of many geophysical parameters as magnetic indices (Triskova, 1989; Cliver et al., 2000, 2001) and the $B_{\mathrm{Z}}$ component of the interplanetary magnetic field (Russell and Pherron, 1973). Three main mechanisms are invoked to explain such an asymmetry: (1) the axial hypothesis, 

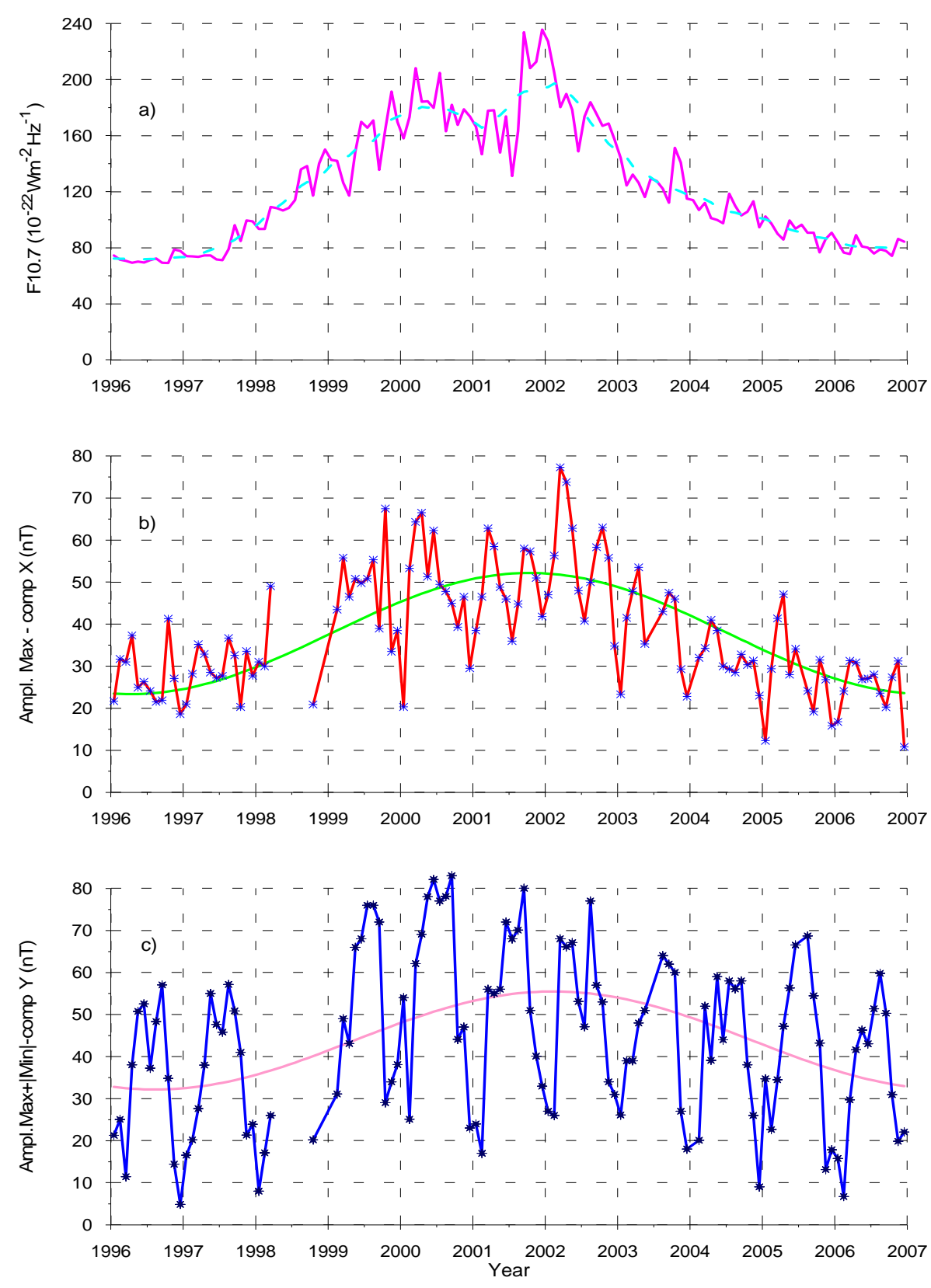

Fig. 4. Solar cycle variation of the F10.7 index and the daily amplitude of the $\mathrm{X}$ and $\mathrm{Y}$ components of the Earth's magnetic field at Phu Thuy during solar cycle 23 (1996-2006). From the top to the bottom: the F10.7 variation (panel a), the daily amplitude of the X component (panel b) and the daily amplitude of the Y component (panel c), computed as the difference between the maximum and the minimum of the daily curve, and averaged for each month of the period. On each panel, the yearly mean variation is superimposed.

(2) the Russell Mac Pherron (RM) effect and (3) the equinoctial hypothesis (Chaman Lal, 1996; Cliver et al., 2002). In our study concerning the magnetic quiet days the axial hypothesis mechanism as well as the Russell Mac Pherron effect are not efficient as they are concerned by magnetic activity and we have selected magnetically quiet days. The RM effect is only related to magnetic disturbed days with IMF $B_{\mathrm{Z}}$ southward.
During solstices, the asymmetry of the ionospheric dynamo between the two hemispheres is larger than during equinoxes, field-aligned currents flowing from the current vortex centre in winter hemisphere to that in summer hemisphere must be taken into account (Fukushima, 1979; Takeda, 1982, 1989, 2002).

We observe that during the solar cycle 23 the two equinox maxima are asymmetric: the autumnal maximum is in general smaller than the spring one. This might be related to 

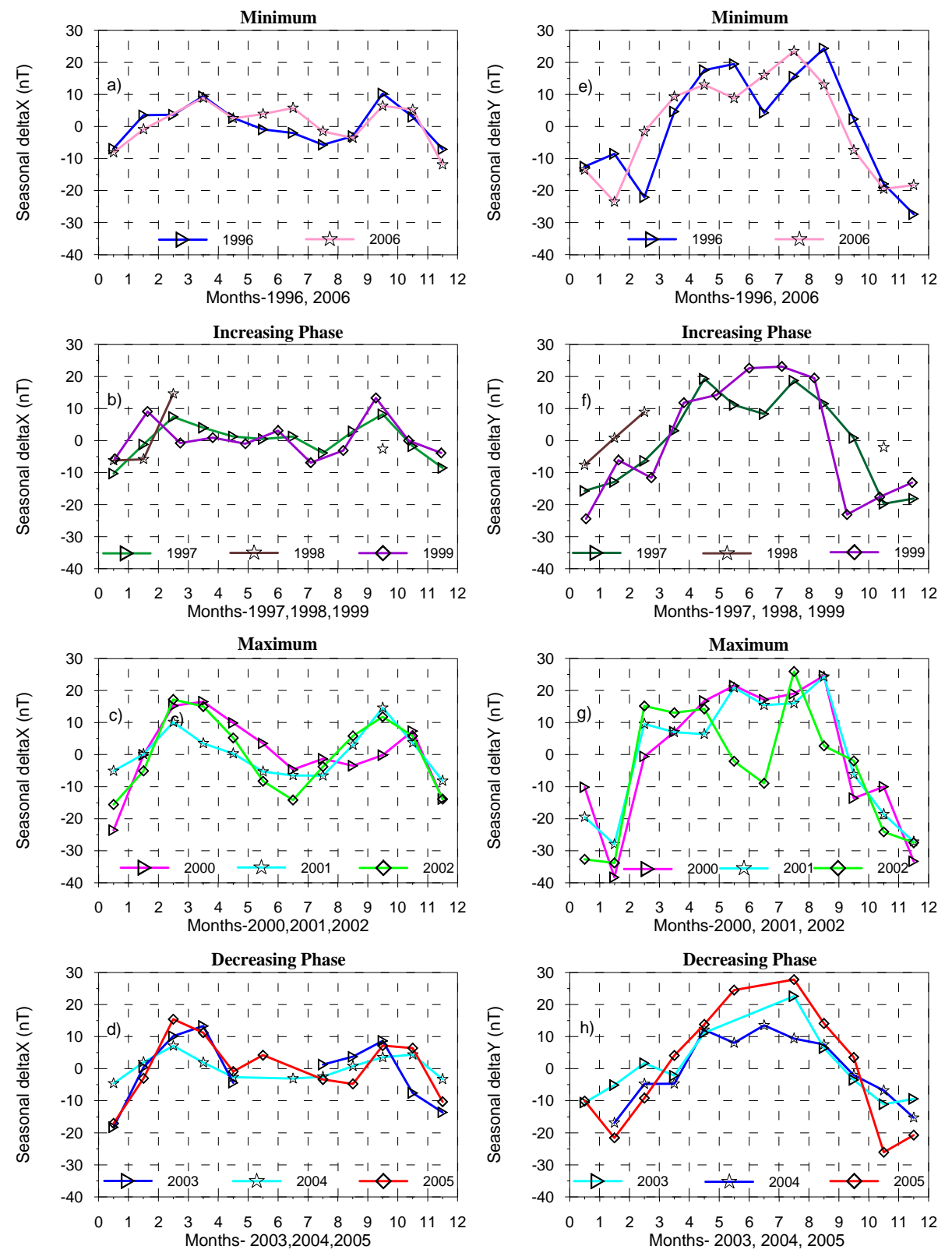

Fig. 5. Seasonal variations of the amplitude of the monthly mean variation of $\Delta X$-component at Phu Thuy, from 1996 to 2006. Panel (a) shows the minimum phase years $\left(R_{z}<20\right)$. Panel (c) illustrates the maximum phase years $\left(R_{z}>100\right)$. Panel (b) is devoted to the increasing phase years $\left(20 \leq R_{z} \leq 100\right)$ and panel (d) to the decreasing phase years $\left(100 \geq R_{z} \geq 20\right)$. Panels (e), (f), (g), (h) correspond to the $\Delta Y$ component.

the lag between the annual cycles of temperature and insolation, and that the nonlinear interactions between tides and planetary waves could be responsible for some features of the seasonal variation of these waves (Campbell and Matsushita, 1982; Takeda, 2002).

$\Delta Y$ component (Fig. 5, right side), exhibits an annual variation with minima mostly during winter months (February or December) for all the phases of the sunspot cycle. During the solar maximum phase, the shape of the $\Delta Y$ component vari- ation increases very strongly from February to March and decreases also strongly from September to October. During the year 2002 a minimum is observed in July. The same minimum is also observed in July of the years 1996 and 1997.

Figure 6 illustrates the mean monthly diurnal variation of $\Delta X$ (left side) and $\Delta Y$ components (right side) observed at Gnangara for the different phases of the sunspot cycle. Gnangara is located in the Southern Hemisphere near the focus of the Sq system in the Asian longitude sector. At 

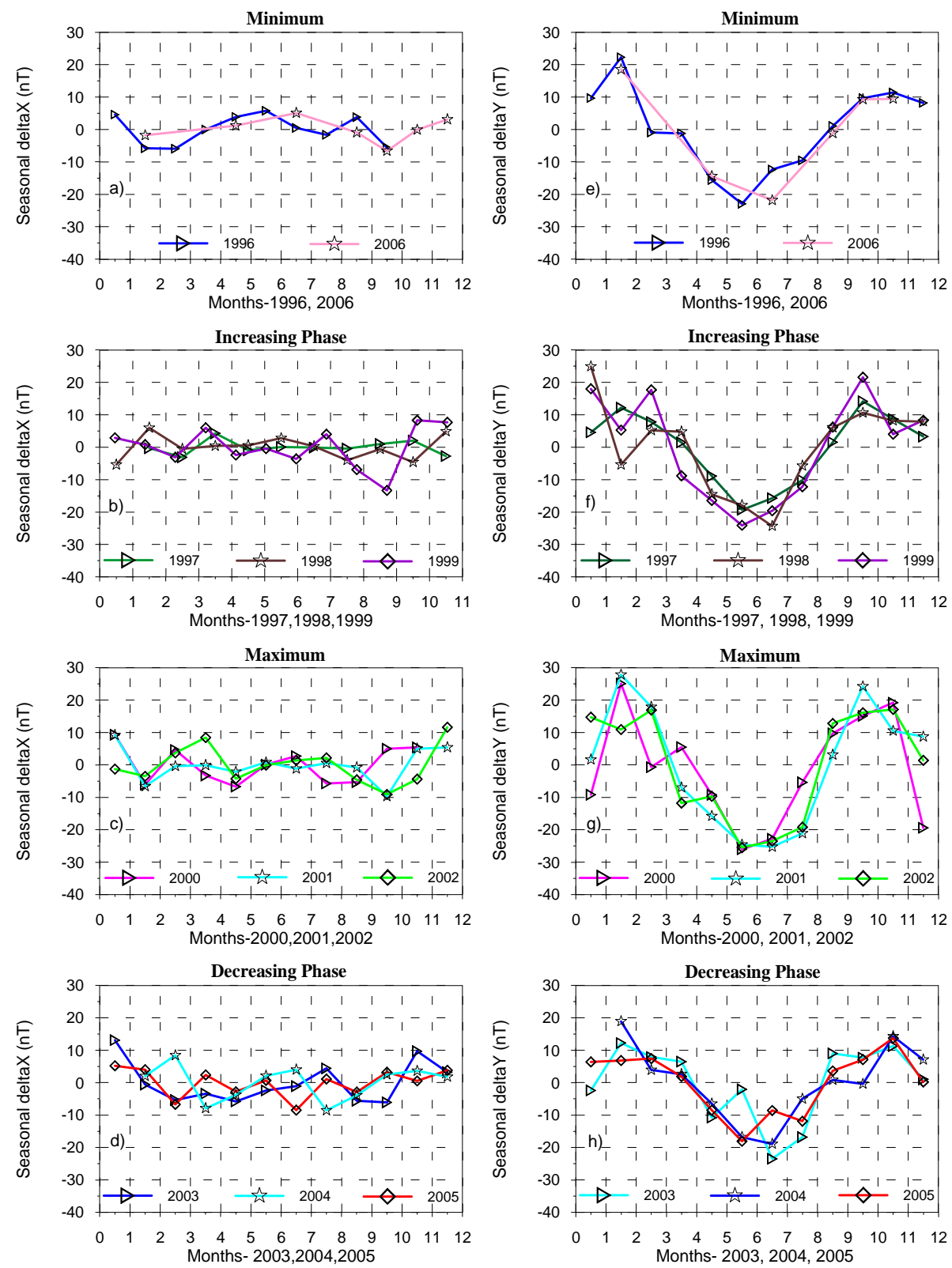

Fig. 6. Similar to Fig. 5 for the observatory of Gnangara.

this observatory the mean amplitude of the $\Delta X$ component is very weak. It is explained by the location of Gnangara near the focus of the Sq current cell, and therefore the semiannual equinox pattern is not visible on the $\Delta X$ component at Gnangara. We choose the Gnangara observatory because there is no magnetic observatory at the same latitude as Phu Thuy in the Southern Hemisphere. Figure 6, right side shows the mean amplitude of the $\Delta Y$ component which exhibits the semiannual pattern with two maxima generally in February and October or November. During the ascending phase there are sometimes three maxima in January, March, and October. Campbell and Schiffmacher (1998) explained these observa- tions by "change in the seasonal cycle of the summertime current vortex pushes across the equator into the opposite, winter hemisphere at low-latitude locations. This wintertime intrusion of currents appears at mostly prenoon hours in the southern hemisphere and at postnoon hours in the northern hemisphere".

Figure 7 illustrates the mean diurnal variation of the Xcomponent at Phu Thuy for spring (left top panel), autumn (left bottom panel), summer (right top panel) and winter (right bottom panel). On each panel the colored curves correspond to the different years of the solar cycle 23 . 

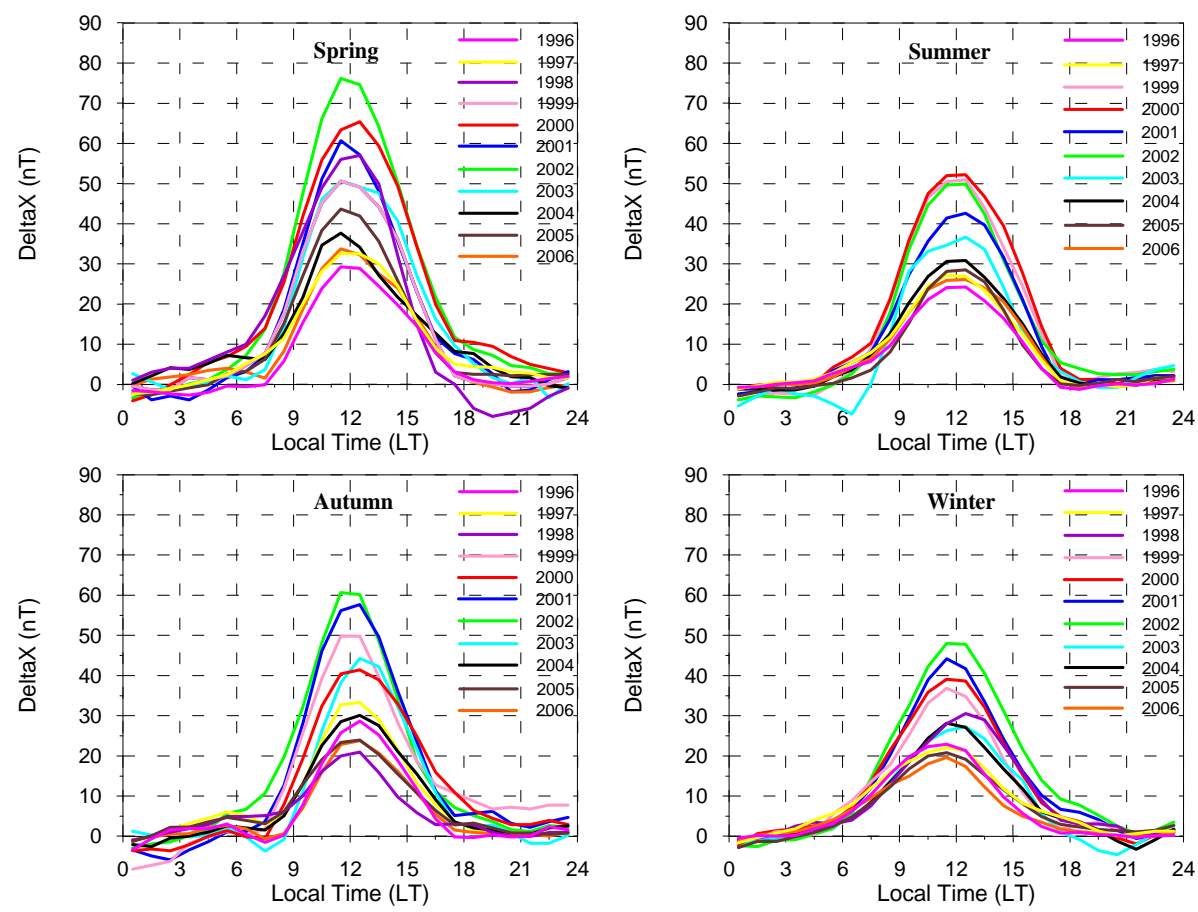

Fig. 7. Seasonal mean diurnal variations of the X-component of the Earth's magnetic field observed at Phu Thuy during quiet magnetic days am $<20$ nT for all the years from 1996 to 2006.

The $\mathrm{X}$ component amplitude during spring is the greatest one $\sim 80 \mathrm{nT}$ at the solar maximum, only $\sim 60 \mathrm{nT}$ during autumn at the solar maximum. The $\mathrm{X}$ component amplitudes in summer and winter are comparable $(\sim 50 \mathrm{nT}$ at solar maximum).

These observations clearly highlight that the two equinoxes are not symmetric.

Previously, in situ measurements of electric fields and neutral winds with incoherent scatter sounder showed the equinoctial asymmetry (Bernard, 1974; Blanc et al., 1977), as well as Sq analysis (Takeda, 2002) showed the equinoctial asymmetry.

Figure 8 presents the mean diurnal variation of the Ycomponent observed at Phu Thuy during each year of the solar cycle 23 for the four seasons. The extreme values of the diurnal variation of the Y-component at Phu Thuy are maxima in summer and minima in winter. The $\mathrm{Y}$ component variation during winter is very different to the spring, summer and autumn ones. In spring, autumn and summer, the morning maximum (ionospheric electric current toward the South) has absolute amplitude greater than the afternoon minimum. In winter the afternoon minimum disappears. This feature called the "winter anomaly" was found previously in the Indian-Siberian region by Campbell et al., 1993. Campbell et al. found (1) that during winter time the mid latitude vortex current disappear (as at Phu Thuy) and (2) that the focus of the Sq currents is at lower latitudes in the East Asia than in Europe and North America. The Phu Thuy ob- servations show that at daily scale the electric current flow toward South is larger than the flow toward North. The fact that the amplitude of the Sq current cell in summer hemisphere is greater than the winter one is explained by a seasonal effect, as the summer hemisphere receives more light from the sun (Fukushima, 1979). But, the asymmetry between the two Sq cells at equinox cannot be explained as previously.

Figure 9 illustrates the local time of the passage to zero (x-axis) of the Y component at Phu Thuy during solar cycle 23. This figure shows that the local time of the passage to zero is in general after 13:00 LT during winter months and before 12:00 LT and sometimes 11:00 LT during summer months. Mascart (1900) analyzed the variations of the declination ( $\mathrm{Y}$ component) and found the same the result. This observation can be interpreted by morphological changes of the global external current system (Matshushita and Maeda, 1965; Takeda, 2002)

\section{Mean daily variations: comparisons with other observatories, some examples}

Figure 10, illustrates the mean diurnal variation of the $X$ components during spring observed for all the years of the solar cycle 23, in the different selected observatories: Phu Thuy, Tamanrasset, M'Bour, San Juan located in the Northern Hemisphere are on the left side. Gnangara, Hermanus, Bangui and Trelew located in the Southern Hemisphere are on the right side. 

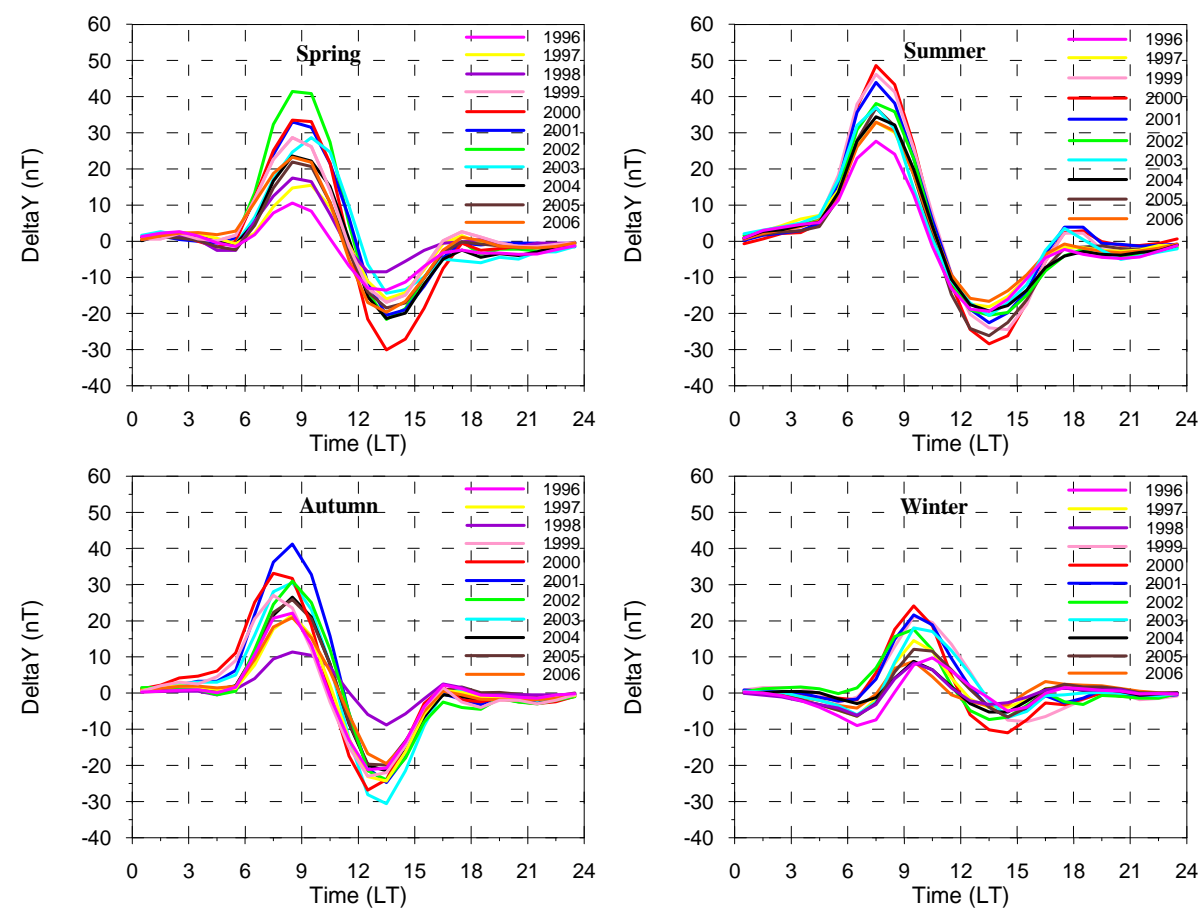

Fig. 8. Figure similar to Fig. 7 for component $Y$.

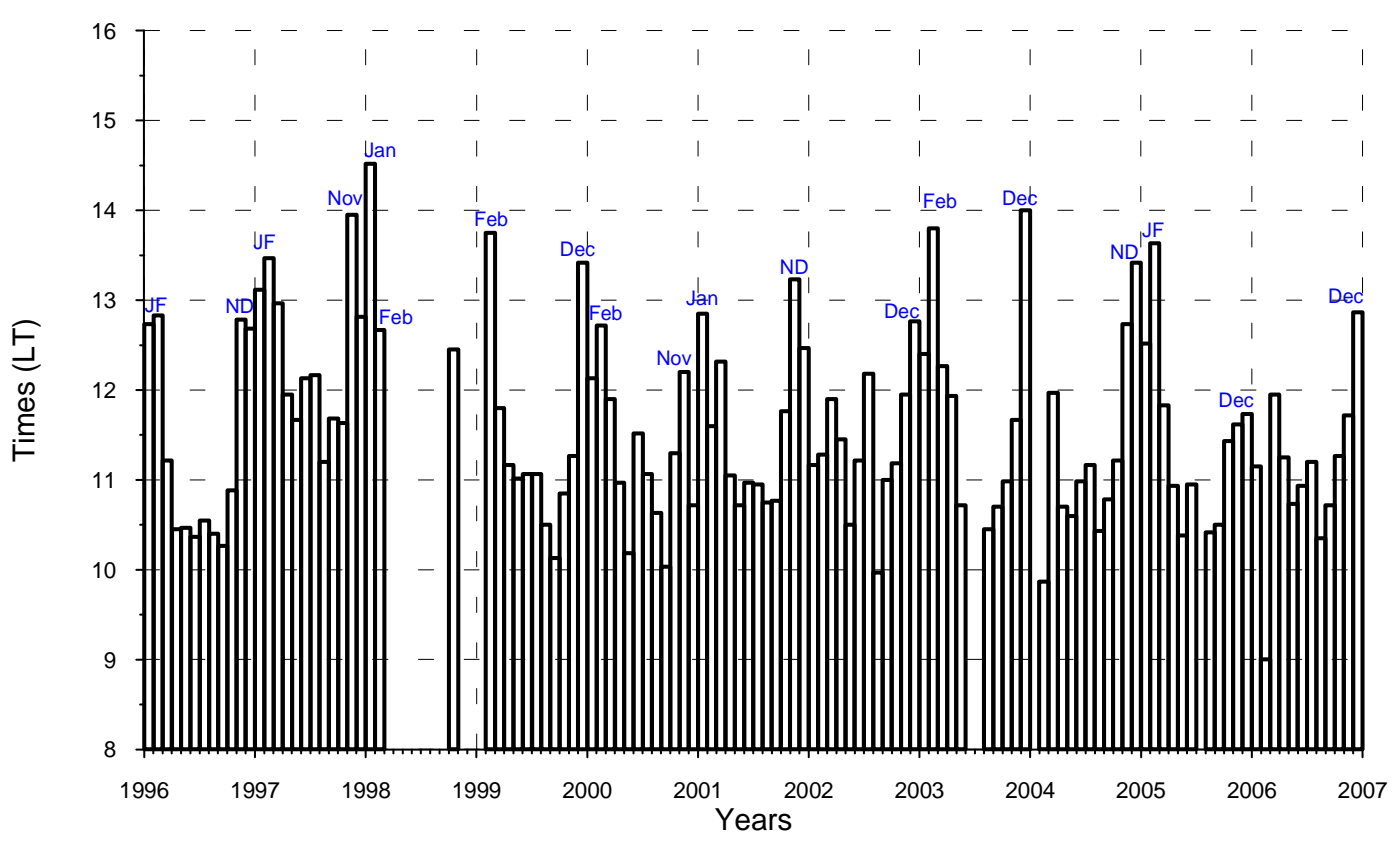

Fig. 9. Mean monthly time of the reversal of the Y component at Phu Thuy for year 1996 to 2006.

At Gnangara, Hermanus and Trelew the amplitude of the northward $\mathrm{X}$ component is small and negative during the most part of the day $(\sim 20 \mathrm{nT})$. This is the typical signature of a station located just southward of the focus of the Sq cell in the Southern Hemisphere. At San Juan the amplitude of the $\mathrm{X}$ component is small and positive during the most of the day $(\sim+30 \mathrm{nT})$. This is the typical signature of a station located southward of the Sq focus in the Northern Hemisphere. The other four observatories Phu Thuy, Tamanrasset, M'Bour and Bangui exhibit the same variation. The $\mathrm{X}$ northward component is positive during the whole day with maximum amplitude during the maximum phase of the sunspot cycle (green 

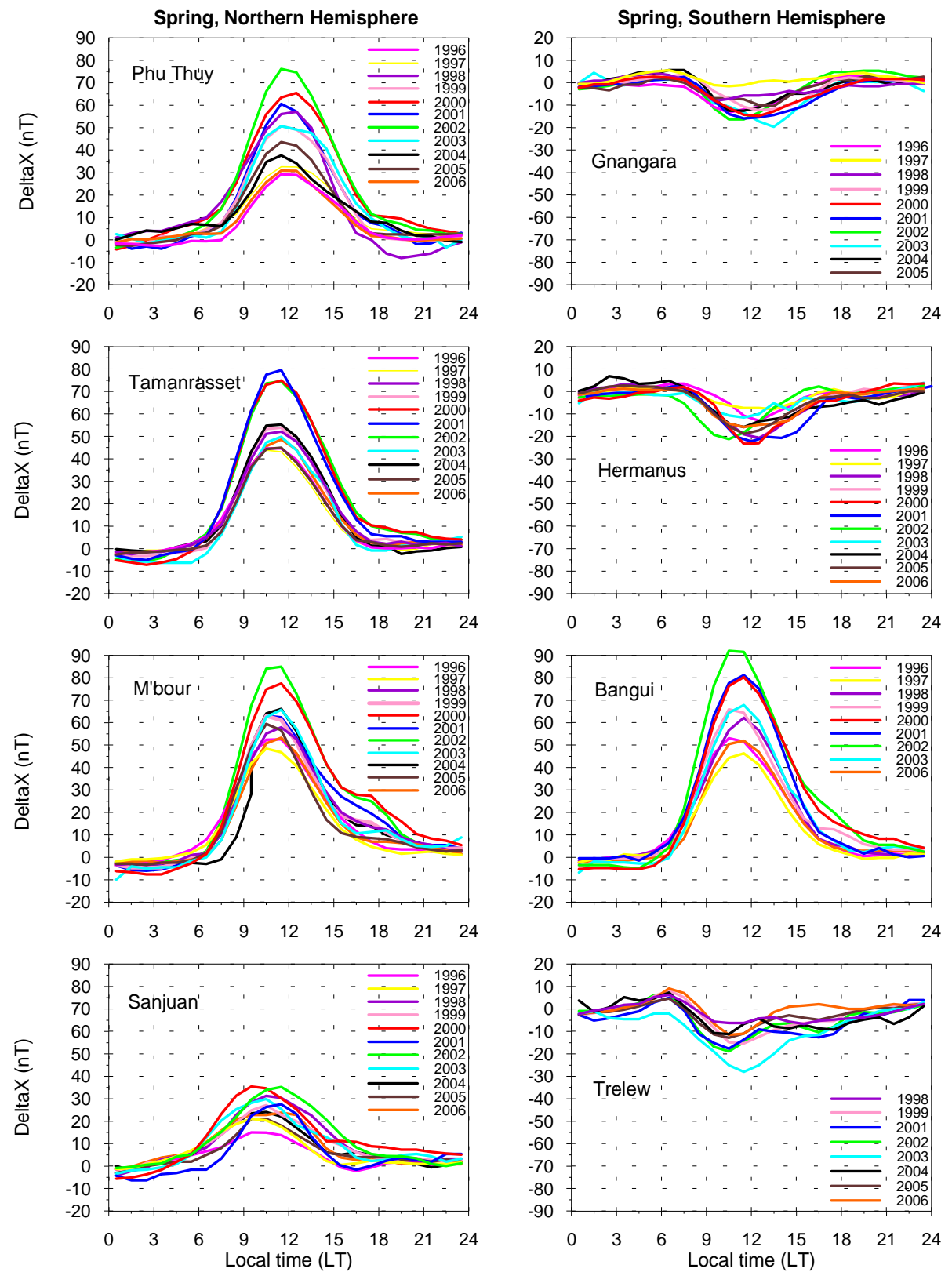

Fig. 10. Seasonal mean diurnal variations of the $X$ component during Spring at Phu Thuy, Gnangara, Tamnarasset, Hermanus, M'Bour, Bangui, San Juan and Trelew from 1996 to 2006 and during quiet magnetic time am <20 nT.

curve - year 2002) around $\sim 75 \mathrm{nT}$ at Phu Thuy, $\sim 80 \mathrm{nT}$ at Tamanrasset, $85 \mathrm{nT}$ at M'Bour and $90 \mathrm{nT}$ at Bangui. This pattern is typical of stations between the focus of the Sq cell and the equatorial electrojet in both hemispheres (Fig. 2). In Fig. 10, many differences are observed from one station to another:

- At Tamanrasset, for the maximum sunspot phase (years 2000-2001-2002), the amplitudes of the $X$ component are similar (between $\sim 75 \mathrm{nT}$ and $\sim 80 \mathrm{nT}$ ) and for all the other sunspot cycle phases (increasing minimum and decreasing), the amplitudes of the $\mathrm{X}$ component are also similar (between $\sim 45 \mathrm{nT}$ to $55 \mathrm{nT}$ )

- At Phu Thuy as well as M'Bour or Bangui, the amplitudes of the $\mathrm{X}$ component vary from the minimum phase to the maximum phase. The largest differences in the amplitudes between the maximum and minimum phases of the sunspot cycle are observed at Phu Thuy ( $\sim 30 \mathrm{nT}$ for the minimum and $\sim 75 \mathrm{nT}$ for the maximum). 

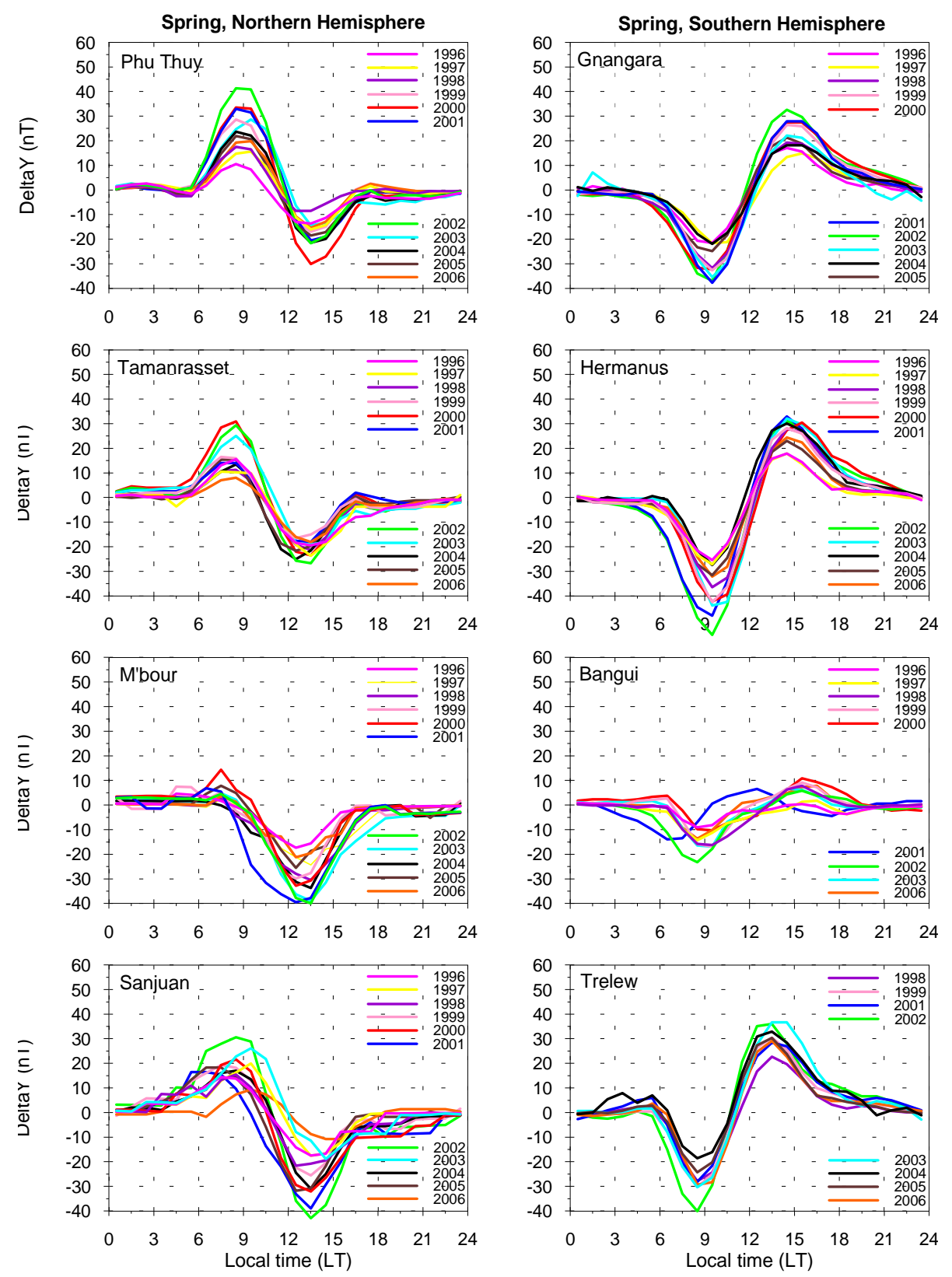

Fig. 11. Seasonal mean diurnal variations of the Y-component during Spring at Phu Thuy, Gnangara, Tamnarasset, Hermanus, M'Bour, Bangui, San Juan and Trelew from 1996 to 2006 and during quiet magnetic time am <20 nT.

- At M'Bour and Bangui the maximum of the X component is never smaller than about $45 \mathrm{nT}$ during the minimum phase of the sunspot cycle.

Figure 11 is similar to Fig. 10 and shows the eastward Y component during spring, for all the selected observatories. All the observatories in the Northern or Southern Hemispheres, except M'Bour and Bangui exhibit the usual Sq pattern: a positive eastward $\mathrm{Y}$ component in the morning and a negative one in the afternoon, in the Northern Hemisphere (Phu Thuy, Tamanrasset, San Juan) and the reverse pattern in the Southern Hemisphere (Gnangara, Hermanus, Trelew).
The amplitude of the $\mathrm{Y}$ component at Bangui is very weak, smaller than about $20 \mathrm{nT}$. This fact is explained by the location of this station near the magnetic equator. At these latitudes the ionospheric current (equatorial electrojet) flows mostly in the eastward direction.

At M' Bour, the morning southward maximum (eastward declination) is very weak, typically $\sim 5 \mathrm{nT}$, compared to the afternoon northward minimum (westward declination) 20 to $20 \mathrm{nT}$, for all the phases of the sunspots cycle This anomaly is related to the North-South asymmetry of the D component (Y component) (Van Sabben, 1964; Mayaud 1965b; Mazaudier and Venkateswaran, 1985). 

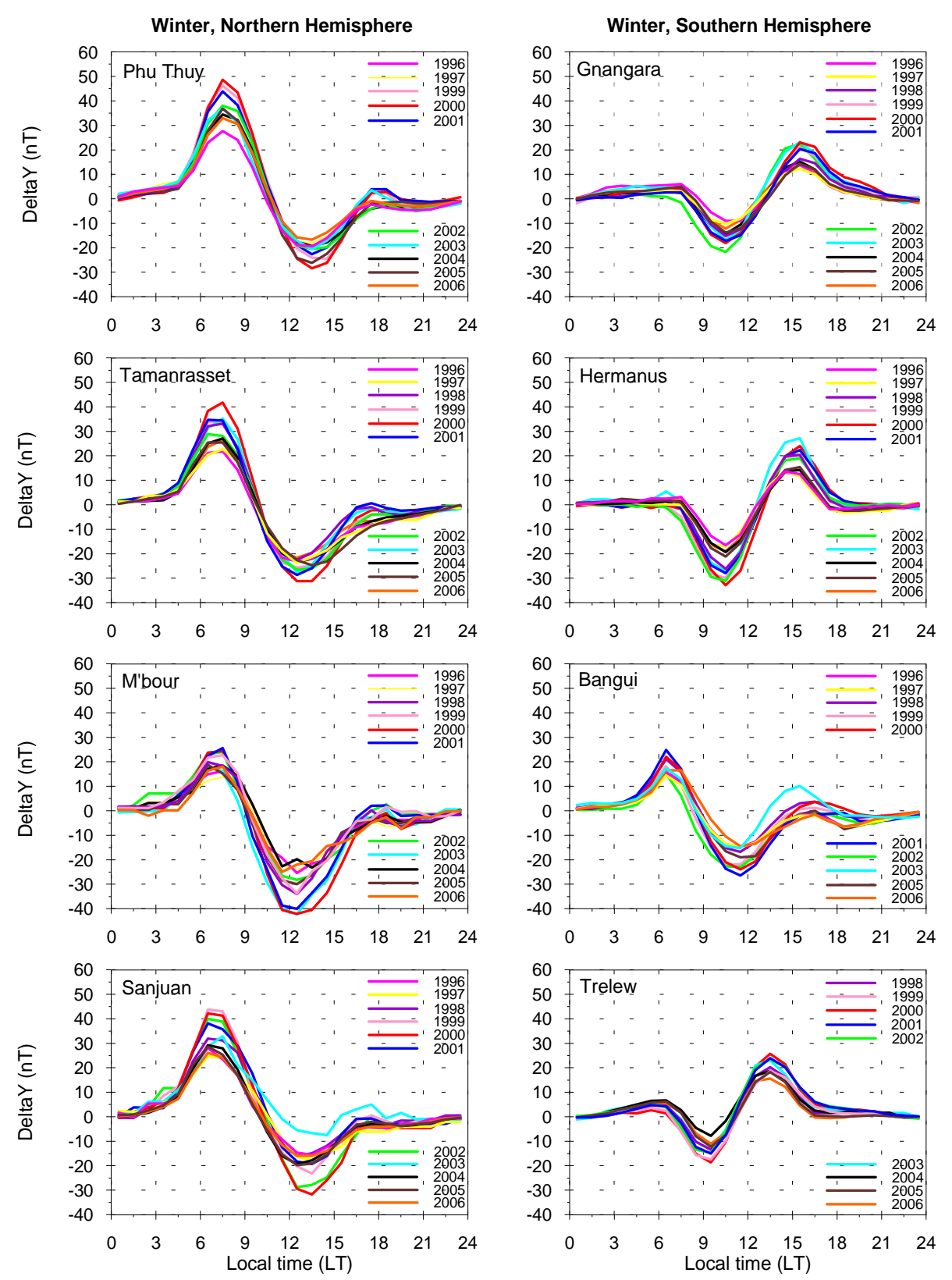

Fig. 12. Similar to Fig. 11 for winter.

In the Southern Hemisphere (Fig. 11, right panels), at Gnangara and Hermanus.

For all the phases of the sunspot cycle, the amplitude of the Y morning extremum is greater than the amplitude of afternoon extremum. At Trelew, both extrema exhibit the same amplitude except for the year 2002 (green curve).

In the Northern Hemisphere (Fig. 11, left panels), the amplitude of the afternoon extrema is greater than the amplitude of the morning extrema except at Phu Thuy. At Phu Thuy the morning maximum is in average between $\sim 20 \mathrm{nT}$ and $30 \mathrm{nT}$ and the afternoon minimum between $\sim 12 \mathrm{nT}$ and $\sim 20 \mathrm{nT}$. We must notice that at Phu Thuy the afternoon minimum is very strong in $2006 \sim 30 \mathrm{nT}$ and the morning maximum very strong in $2002 \sim 40 \mathrm{nT}$.

At Tamanrasset (Fig. 11), during all the phases of the sunspot cycle, except for the maximum phase, the morning maximum is in average between $8 \mathrm{nT}$ and $15 \mathrm{nT}$ and the afternoon minimum between $-18 \mathrm{nT}$ and $-25 \mathrm{nT}$. During the maximum phase $(2000,2001,2002)$ the morning maximum is between $25 \mathrm{nT}$ and $30 \mathrm{nT}$ and the afternoon minimum between $-18 \mathrm{nT}$ and $-25 \mathrm{nT}$.

At San Juan, for all the phases of the sunspot cycle the afternoon extremal amplitude is greater than the morning one. 
It is in the African sector that the largest amplitude differences of the Y eastward component are observed between the two hemispheres. Mayaud (1965b) explained these observations by the interaction between the two hemispheric systems CM. Mayaud (1965b) found that the Sq vortex of the Northern Hemisphere can extend to southern latitudes. This fact introduces a strong asymmetry between the two extremes of the Y/D component.

Figure 12 presents the variations of the eastward Y component of the Earth's magnetic field for the winter season. In the Northern Hemisphere, for all the phases of the sunspot cycle, at Phu Thuy in the Asian sector, Tamanrasset and M'Bour in the African sector. The amplitude of the morning positive maximum (southward ionospheric electric current) is smaller than the amplitude of the afternoon negative minimum (northward ionospheric electric current). At M'bour, there is no morning maximum as during the spring season (see Fig. 11). At Phu Thuy, there is no northward electric current flow during afternoon (westward deviation of the magnetic field). San Juan is the only station of the Northern Hemisphere showing the usual pattern. In the Southern Hemisphere, Gnangara, Hermanus and Trelew have similar variations, but we must notice that at Gnangara and Hermanus the morning westward maximum is larger than the afternoon eastward maximum. At San Juan it is the afternoon eastward maximum which is larger than the morning westward maximum. The variation of the mean diurnal $\mathrm{Y}$ component observed at Bangui during winter is similar to the variation observed in spring (see Fig. 11).

\section{Discussion and conclusion}

In Table 3 we recapitulate our main results. The number of the corresponding figure is given for the different results. The rows correspond to the different characteristics observed on the data and the columns to the different observatories. We analyzed and quantified in details the characteristics of the equinoctial asymmetry for all observatories and for the different years of the solar cycle 23 (not shown in this paper but summarized in Table 3).

This table shows the variation of the $\mathrm{X}$ and $\mathrm{Y}$ components relationship above mentioned (rows 1, 2, 3, 4, 5, 6 of Table 3).

Thus, the spring $\mathrm{X}$ component amplitude is usually larger than the autumn $\mathrm{X}$ component amplitude in both hemispheres (row 1). Nevertheless during some years this pattern is reversed. Line 2 of Table 3 gives the years of reversal. The italic characters mean that the difference between spring and autumn is smaller than $5 \mathrm{nT}$ and therefore not significant. The bold characters represent years for which the difference between spring and autumn is significant $(>5 \mathrm{nT})$.

The general equinoctial tendency of the $\mathrm{Y}$ component for spring (row 3) and autumn (row 5) is a larger amplitude of the morning extremum than the amplitude of the afternoon one, except at Phu Thuy for the 2 equinoxes and Trelew for the autumnal equinox.

At Phu Thuy, in spring and autumn the amplitude of the morning eastward maximum (Max Y) is larger than the afternoon westward extremum (Min Y). Nevertheless, for each observatory, this tendency can be reversed for several years. Rows 4 and 6 of Table 3 gives the years of reversal for the spring and autumn seasons. As for the $\mathrm{X}$ component italic characters corresponds to a difference smaller than $5 \mathrm{nT}$ and bold characters to a difference greater than $5 \mathrm{nT}$.

In Table 3, row 7, is also given the significance of the correlation coefficient of $\mathrm{X}$ component with F10.7. This correlation coefficient is rather good at Phu Thuy and Bangui, and less so for other observatories.

The semiannual variation of the $\mathrm{X}$ component is found in all the observatories of the Northern Hemisphere (row 8, columns $1,2,3,4)$. This is related to the semiannual variation of the atmospheric winds (Mukhtarov et al., 2009) together with the delay by about 1 or 2 months of the movement of the current vortices from the solstices due to the magnetic effect by the field-aligned currents flowing from current vortex center in winter hemisphere to that in summer hemisphere (Fukushima, 1979; Takeda, 1989, 2002). The semi-annual variation is not observed at all the stations located near the focus of the Southern Hemisphere. This can be explained by the motions of the focus which hide this variation.

The annual variation of the daily amplitude of the Y component reaches its maximum in the summer hemisphere and its minimum in the winter hemisphere (figures not shown). This can be explained by the field-aligned currents flowing from the summer to the winter hemisphere in the morning and reversely in the afternoon (Fukushima, 1979) and by Ycomponent amplitude increase in summer and decrease in winter (Takeda, 1982, 1991). In the Northern Hemisphere, an annual variation of the Y component is observed (row 9, columns 1, 2, 3,4). In the Southern Hemisphere a semi annual variation of the $\mathrm{Y}$ component is observed (row 10, columns $5,7,8)$.

The semiannual variation of the $\mathrm{Y}$ component at Gnangara (row 10, column 5) and all the stations of the Southern Hemisphere (not shown in the paper) is a characteristic of quiet ionospheric currents of the Southern Hemisphere. This must be explained by the change in the seasonal cycle of the summertime current vortex pushing across the equator into the opposite, winter hemisphere at low-latitude locations (Campbell and Schiffmacher, 1988) and by atmospheric motions.

The winter anomaly observed in $\mathrm{Y}$ component at Phu Thuy (row 11, column 1) results from the focus position of the Sq currents at lower geomagnetic latitude in the East Asia than in Europe and North America (Campbell et al., 1993). The position of Sq currents was affected by the position of the geographic and geomagnetic poles with respect to these regions (Campbell and Schiffmacher, 1985). 
Table 3. Characteristics of our observations.

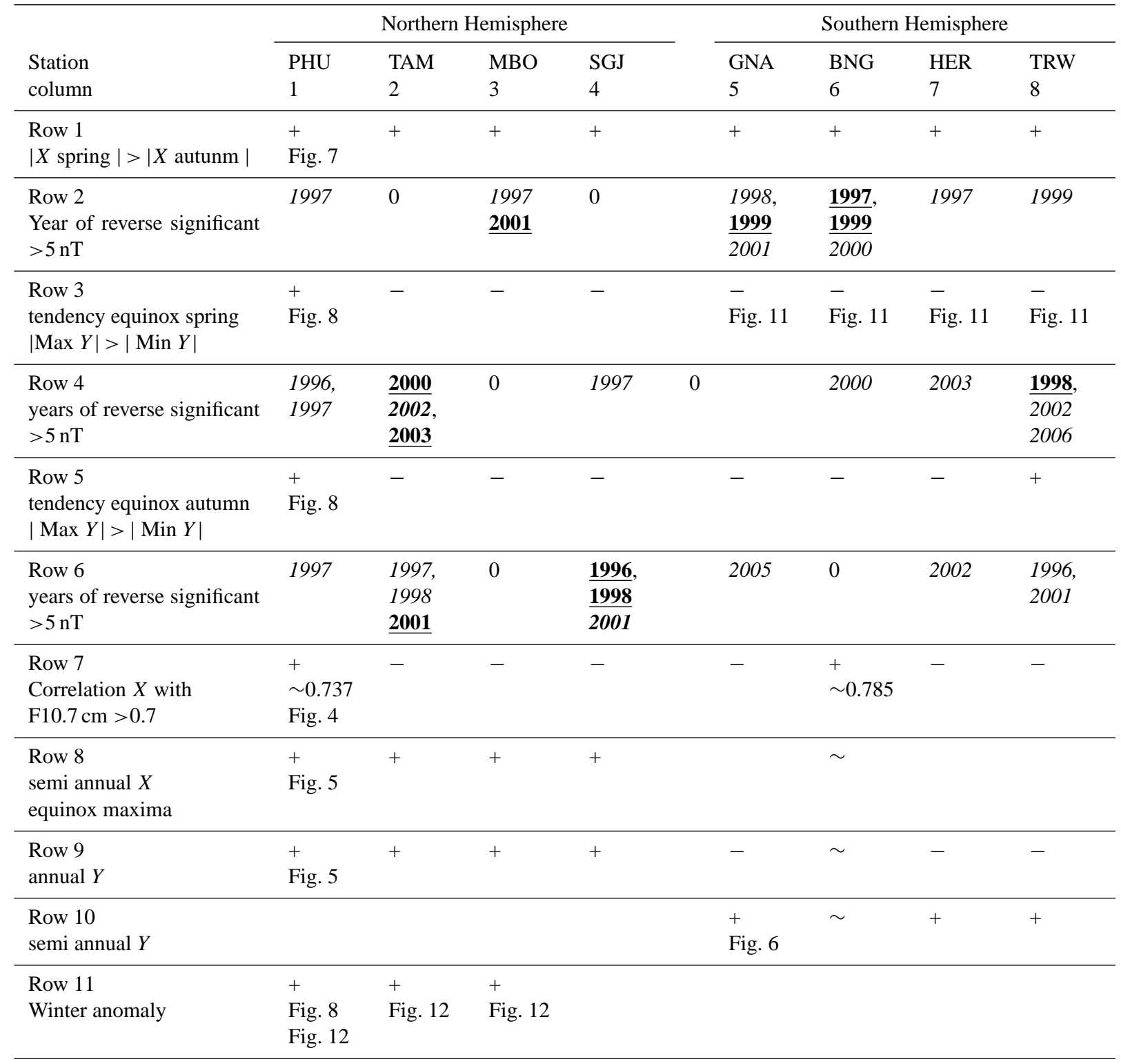

In the African sector of the Northern Hemisphere at Tamanrasset and M'bour (row 11, columns 2, 3), the Y morning maximum, in winter, is very small or disappears: this was previously observed on magnetic data by Van Sabben (1964), Mayaud (1965b) and also on incoherent scatter sounder data by Mazaudier and Venkateswaran (1985). We must recall here that the African stations used in this study are located at lowest latitudes than the stations in Asian and American sectors.

This study shows many asymmetries in latitude, longitude and between the two hemispheres. This is the result of the longitudinal, latitudinal and hemispherical asymmetries in the neutral wind, main source of the Sq current (Richmond and Roble, 1987; Olsen, 1997; Akmaev, 2001; Hagan and Forbes, 2002, 2003).

Rastogi et al. (1994) analyzed the data of the Indian chain of 9 magnetometers during the solar cycle 21 . They characterized the diurnal variation of the $\mathrm{Y}$ component, the semi diurnal variation of the $\mathrm{X}$ component and the equinoctial asymmetry observed also at Phu Thuy. The magnetic observations in the Indian and Vietnamese sectors differ particularly at equatorial latitudes where the strength of the equatorial electrojet in larger in the Vietnamese sector than in the Indian sector (Doumouya et al., 2003; Doumbia et al., 2007). 
Phu Thuy is located in the Asian sector, below the focus of the Sq current. Here the declination of the Earth's magnetic field is very weak. Phu Thuy is at the geographic latitude of $21.03^{\circ} \mathrm{N}$ and magnetic apex latitude of $14.09^{\circ} \mathrm{N}$ at the crest of the equatorial anomaly. All these characteristics must be used in further modeling of the regular Sq current system at Phu Thuy.

Campbell et al. (1993), found that in the Asian sector the focus of the Sq current system is at lower geomagnetic latitude $\sim 22^{\circ}$ than in Europe or North America sectors $\sim 29^{\circ}$. Tarpley (1973) related the equinoctial enhancement of the equatorial electrojet to the equatorward motions of the $\mathrm{Sq}$ current system focus. Therefore the fact that the Sq current focus is at a lower latitudes in the Asian sector can explain the maximum observed in the equatorial electrojet in the Vietnamese sector, even through the internal magnetic field is strong (IGRF model http://ccmc.gsfc.nasa.gov/modelweb/).

In conclusion the three main characteristics of the Vietnamese $\mathrm{Sq}$ are:

1. the equinoctial asymmetry: the spring Sq amplitude is greater than the autumn $\mathrm{Sq}$ amplitude

2. the winter anomaly: the $\Delta Y$ afternoon minimum disappears

3. the $\Delta Y$ asymmetry: the morning extremum amplitude is always greater than the afternoon extremum and this implies an ionospheric electric current flow more southward than northward during the day.

All these morphological characteristics of the Sq current system in Vietnam have to be understood by using dynamo modeling taking into account the neutral wind source. Further research is needed.

Acknowledgements. The authors thank the Centre d'Etude des Environnements Terrestre (CETP) and the INTERMAGNET project who contributed to collection and data processing during this research. This work is financed by the Vietnam Academy of Science and Technology, the Vietnam Ministry of Education and Training, and the French Centre National de Recherche Scientifique. The authors thank Paul and Gérard Vila for their English corrections.

Topical Editor M. Pinnock thanks K. Yumoto, J. M. Torta, and two other anonymous referees for their help in evaluating this paper.

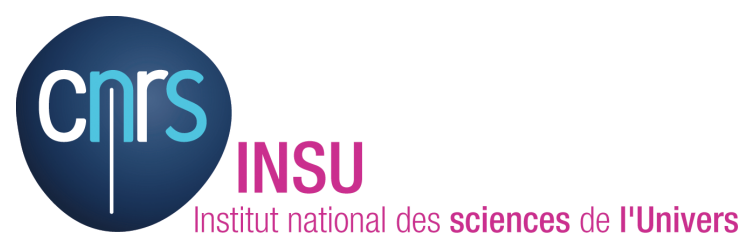

The publication of this article is financed by CNRS-INSU.

\section{References}

Akmaev, R. A.: Seasonal variation of the terdiurnal tide in the mesosphere and Lower thermosphere: a model study, Geophys. Res. Lett., 28(19), 3817-3820, 2001.

Amory-Mazaudier, C., Le Huy, M., Cohen, Y., Doumbia, V., Bourdillon, A., Fleury, R., Fontaine, B., Ha Duyen, C., Kobea, A., Laroche, P., Lassudrie-Duchesne, P., Le Viet, H., Le Truong, T., Luu Viet, H., Menvielle, M., Nguyen Chien, T., Nguyen Xuan, A., Ouattara, F., Petitdidier, M., Pham Thi Thu, H., Pham Xuan, T., Philippon, N., Tran Thi, L., Vu Thien, H., and Vila, P.: Sun-Earth System Interaction studies over Vietnam: an international cooperative project, Ann. Geophys., 24, 3313-3327, doi:10.5194/angeo-24-3313-2006, 2006.

Bernard, R.: Tides in the $E$-region observed by incoherent scatter over Saint Santin, J. Atmos. Terr. Phys., 36, 1105-1120, 1974.

Blanc, M., Amayenc, P., Bauer, P., and Taieb, C.: Electric field induced drifts from the French incoherent scatter facility, J. Geophys. Res., 82(1), 87-97, 1977.

Brekke, A., Doupnik, J. R., and Banks, P. M.: Incoherent scatter measurements of E region conductivities and, J. Geophys. Res., 79(25), 3773-3789, 1974.

Campbell, W.: Annual and semiannual changes of the quiet daily variations $(\mathrm{Sq})$ in the geomagnetic field at north American locations, J. Geophys. Res., 87(A2), 785-796, 1982.

Campbell, W. H. and Matsushita, S.: Sq currents: a comparison of quiet and active year behavior, J. Geophys. Res., 87(A7), 53055308, 1982.

Campbell, W. H. and Schiffmacher, E. R.: Quiet ionospheric currents of the northern hemisphere derived from geomagnetic field records, J. Geophys. Res., 90(A7), 6475-6486, 1985.

Campbell, W. H. and Schiffmacher, E. R.: Quiet ionospheric currents of the northern hemisphere derived from geomagnetic field records, J. Geophys. Res., 91(A8), 9023-9024, 1986.

Campbell, W. H., Arora, B. R., and Schiffmacher, E. R.: External Sq currents in the India-Siberia region, J. Geophys. Res., 98(A3), 3741-3752, 1993.

Chaman Lal: Seasonal trend of geomagnetic activity derived from solar-terrestrial geometry confirms an axial-equinoctial theory and reveals deficiency in planetary indices, J. Atmos. Terr. Phys., 58(13), 1497-1506, 1996.

Chapman, S. and Bartels, J.: Geomagnetism, Oxford University Press, New York, 1940.

Cliver, E. W., Kamide, Y., and Ling, A. G.: Mountain versus valleys: Semiannual variation of geomagnetic activity, J. Geophys. Res., 105(A2), 2413-2424, 2000.

Cliver, E. W., Kamide, Y., and Ling, A. G., and Yokoyama, N.: Semiannual variation of the geomagnetic Dst index: Evidence for a dominant non storm component, J. Geophys. Res., 106(A10), 21297-21304, 2001.

Cliver, E. W., Kamide, Y., and Ling, A. G.: The semiannual variation of geomagnetic activity: phase and profiles for 130 years of aa data, J. Atmos. Solar-Terr. Phys., 64, 47-53, 2002.

Davis, T. N., Burrows, K., and Stolarik, J. P.: A latitude survey of the equatorial electrojet with rocket-borne magnetometers, J. Geophys. Res., 72, 1845-1861, 1967.

Dougherty, J.-P.: Some comments on dynamo theory, J. Geophys. Res., 68(9), 2383-3241, 1963.

Doumbia, V., Maute, A., and Richmond, A. D.: TIEGCM simulation of equatorial electrojet magnetic effects, J. Geophys. Res., 
112, A09309, doi:10.1029/2007JA12308, 2007.

Doumouya, V., Vassal, J., Cohen, Y., Fambitakoye, O., and Menvielle, M.: Equatorial electrojet at African longitudes: first results from magnetic measurements, Ann. Geophys., 16, 658666, doi:10.1007/s00585-998-0658-9, 1998.

Doumouya, V., Cohen, Y., Arora, B. R., and Yumoti, K.: Local time and longitude dependence of the equatorial electrojet magnetic effects, J. Atmos. Solar-Terr. Phys., 65, 1265-1282, 2003.

Fambitakoye, O.: Effets induits par l'électrojet equatorial au centre de l'Afrique, Ann. Géophys., 29(2), 149-169, 1973.

Fukushima, N.: Electric potential between conjugate points in middle latitudes caused by asymmetric dynamo in the ionosphere, J. Geomagn. Geoelectr., 31, 401-409, 1979.

Hagan, M. E. and Forbes, J. M.: Migrating and non migrating diurnal tides in the middle and upper atmosphere excited by tropospheric latent heat release, J. Geophys. Res., 107(D24), 4754, doi:10.1029/2001JD0012361, 2002.

Hagan, M. E. and Forbes, J. M.: Migrating and non migrating semidiurnal tides in the upper atmosphere excited by tropospheric latent heat release, J. Geophys. Res., 108(A2), 1062, doi:10.1029/2002JA009466, 2003.

Harper, R. M.: A comparison of ionospheric currents, magnetic variations, and electric field at Arecibo, J. Geophys. Res., 82(22), 3233-3241, 1977.

Kamide, Y. and Brekke, A.: Auroral electrojet current density deduced from the Chatanika radar and from the Alaska Meridian Chain of magnetic observatories, J. Geophys. Res., 80(4), 587593, 1975.

Kuvshinov, A., Manoj, C., Olsen, N., and Sabaka, T.: On the induction effect of geomagnetic daily variations from equatorial electrojet and solar quiet sources at low and middle latitudes, J. Geophys. Res., 112, B10102, doi:10.1029/2007JB004955, 2007.

Matshushita, S.: Global presentation of the external Sq and L current systems, J. Geophys. Res., 70(17), 4395-4398, 1965.

Matshushita, S., and Maeda, H.: On the Geomagnetic Quiet Daily Variation Field during the IGY, J. Geophys. Res., 70(11), 25352557, 1965.

Mayaud, P. N.: Analyse morphologique de la variabilité jour à jour de la variation journalière "régulière " $\mathrm{Sr}$ du champ magnétique terrestre, 1 , le système de courants $\mathrm{Cp}$ (régions polaires et subpolaires), Ann. Geophys., 21, 369-401, 1965a.

Mayaud, P. N.: Analyse morphologique de la variabilité jour à jour de la variation journalière "régulière " $\mathrm{Sr}$ du champ magnétique terrestre, 2, le système de courants CM (régions non-polaires), Ann. Geophys., 21, 515-544, 1965b.

Mayaud, P. N.: About the effects induced by the daily variation due to the equatorial electrojet, J. Atmos. Terr. Phys., 36, 1367-1376, 1974.

Maynard, N. C.: Measurement of ionospheric currents off the coast of Peru, J. Geophys. Res., 72, 1867-1875, 1967.

Mazaudier, C.: Electric currents Above Saint-Santin, J. Geophys. Res., 87(A4), 2459-2464, 1982.

Mazaudier, C. and Venkateswaran, S. V.: Strange currents over Saint-Santin, J. Geophys. Res., 90(A10), 9727-9735, 1982.

Monro, P. E., Metchly, E. A., and Sastry, R. S.: Analysis of Ordinary Mode Standing Waves observed by Rockets in the E region, J. Geophys. Res., 73(13), 4291-4297, 1968.

Mukhtarov, P., Pancheva, D., and Andonov, B.: Gobal structure and seasonal and interannual variability of the migrat- ing diurnal tide seen in the SABER/TIMED temperatures between 20 and $120 \mathrm{~km}$, J. Geophys. Res., 114, A02309, doi:10.1029/2008JA13759, 2009.

Olsen, N.: The contribution of magnetospheric currents to Sq, Pure Appl. Geophys., 131, 447-462, 1989.

Olsen, N.: Geomagnetic Tides and Related Phenomena in Tidal Phenomena, Lecture Notes in the Earth Sciences, vol. 66, edited by: Wilhelm, H., Zuern, W., and Wenzel, H.-G., Springer, 261274, 1997.

Rastogi, R. G., Alex, S., and Patill, A.: Seasonal Variations of Geomagnetic D, H and Z fields at low latitudes, J. Geom. Geoelectr., 46, 115-126, 1994.

Richmond, A. D.: Ionospheric Electrodynamics, in: Handbook of Atmospheric Electrodynamics, Vol. II, edited by: Volland, H., pp. 249-290, CRC press, Boca Raton, Florida, 1995a.

Richmond, A. D.: Ionospheric electrodynamics using Magnetic Apex coordinates, J. Geomagn. Geoelectr., 47, 191-212, 1995.

Richmond, A. D. and Roble, R. G.: Electrodynamics effects of Thermospheric Winds from the NCAR Thermospheric General Circulation Model, J. Geophys. Res., 92, 12365-12376, 1987.

Russell, C. T. and Mc Pherron, R. C.: Semi annual of Geomagnetic activity, J. Geophys. Res., 78, 92-99, 1973.

Salah, J. E. and Evans, J. V.: Test of electrodynamic consistency from daytime ionospheric drift observations, J. Geophys. Res., 82(16), 2413-2417, 1977.

Sastry, T. S. G.: Daily Variation of Geomagnetic Field at the Indian Stations under the Electrojet during the Period of the July 1966 Proton Flare, J. Geophys. Res., 78(10), 1692-1698, 1973.

Satya Prakkash, Gupta, S. P., and Subbaraya, B. H.: A study of the irregularities in the night time equatorial E-region using a Langmuir probe and plasma noise probe, Planet. Space Sci., 18, 1307-1318, 1970.

Shuman, B. J.: Rocket measurement of the equatorial electrojet, J. Geophys. Res., 75, 3889-3901, 1970.

Takeda, M.: Three dimensional ionospheric currents and field aligned currents generated by asymmetrical dynamo action in the ionosphere, J. Atmos. Terr. Phys., 44(2), 187-193, 1982.

Takeda, M.: Geomagnetic field variation and the equivalent current system generated by an ionospheric dynamo at the solstice, J. Atmos. Terr. Phys., 52(1), 59-67, 1990.

Takeda, M.: Time variation of global geomagnetic Sq field in 1964 and 1980, J. Atmos. Solar-Terr. Phys., 61, 765-774, 1999.

Takeda, M.: Features of global geomagnetic $\mathrm{Sq}$ field from 1980 to 1990, J. Geophys. Res., 107(A9), 1251, doi:10.1029/2001J009210, 2002a.

Takeda, M.: The correlation between the variation in inospheric conductivity and that of the geomagnetic and that of the geomagnetic Sq field, J. Atmos. Solar-Terr. Phys., 64, 1617-1621, 2002 b.

Takeda, M. and Iyemori, T.: Relationship between electric field and currents in the ionosphere and the geomagnetic Sq field, J. Geophys. Res., 108(A5), 1183, doi:10.1029/2002JA009659, 2003.

Tarpley, J. D.: Seasonal movement of the Sq current foci and related effects in the equatorial electorial electrojet, J. Atmos. Solar-Terr. Phys., 35, 1063-1071, 1973.

Torta, J. M., Marsal, S., Curto, J. J., and Gaya-Piqué, L. R.: Behaviour of the quiet-day geomagnetic variation at Livingston island and variability of the $\mathrm{Sq}$ focus position in the SouthAmerican-Antarctic Peninsula region. Earth Planets Space, 62, 
297-307, 2010.

Trikova, L.: The vernal-autumnal asymmetry in the seasonal variation of geomagnetic activity, J. Atmos. Terr. Phys., 51(2), 111$118,1989$.

Vandzandt, T. E, Clark, W. L., and Warnock, J. M.: Magnetic Apex Coordinates : a magnetic coordinate system for the ionospheric F2 layer, J. Geophys. Res., 77, 2406-2411, 1972.
Yamazaki, Y., Yuomoto, K., Uozumi, T., Yoshiwara, A., and Cardinal, M. G.: Equivalent current systems for the annual and semiannual $\mathrm{Sq}$ variations observed along the $210^{\circ} \mathrm{MM}$ CPMN stations, J. Geophys. Res., 114, A12320, doi:10.1029/2009JA014638, 2009. 